Meta

Journal des traducteurs

Translators' Journal

\title{
A Socialist Approach to Translation: A Way Forward?
}

\section{Gabriele Thomson-Wohlgemuth}

Volume 49, numéro 3, septembre 2004

L'histoire de la traduction et la traduction de l'histoire

History of Translation and Translation of History

URI : https://id.erudit.org/iderudit/009375ar

DOI : https://doi.org/10.7202/009375ar

Aller au sommaire du numéro

Éditeur(s)

Les Presses de l'Université de Montréal

ISSN

0026-0452 (imprimé)

1492-1421 (numérique)

Découvrir la revue

Citer cet article

Thomson-Wohlgemuth, G. (2004). A Socialist Approach to Translation: A Way Forward? Meta, 49(3), 498-510. https://doi.org/10.7202/009375ar

\section{Résumé de l'article}

À l'intérieur de la République démocratique allemande (RDA) dans le contexte de la Guerre froide, une nouvelle approche dans les processus impliqués pour la traduction littéraire, ainsi qu'une réorganisation de l'industrie de la publication ont vu le jour. En reconnaissant la traduction comme étant une pratique sociale, la RDA a établi des conditions qui incluent l'environnement de travail avec l'objectif de produire des traductions de haute qualité. En reconnaissant la signification historique de cette approche, il est possible de l'adapter à la société contemporaine. Nous croyons que cette approche peut amener une contribution constructive à la traductologie.
Ce document est protégé par la loi sur le droit d'auteur. L'utilisation des services d'Érudit (y compris la reproduction) est assujettie à sa politique d'utilisation que vous pouvez consulter en ligne.

https://apropos.erudit.org/fr/usagers/politique-dutilisation/ 


\title{
A Socialist Approach to Translation: A Way Forward?
}

\author{
GABRIELE THOMSON-WOHLGEMUTH \\ University of Surrey, Guildford and Roehampton, London, United Kingdom \\ gaby@asgard1.freeserve.co.uk
}

\begin{abstract}
RÉSUMÉ
À l'intérieur de la République démocratique allemande (RDA) dans le contexte de la Guerre froide, une nouvelle approche dans les processus impliqués pour la traduction littéraire, ainsi qu'une réorganisation de l'industrie de la publication ont vu le jour. En reconnaissant la traduction comme étant une pratique sociale, la RDA a établi des conditions qui incluent l'environnement de travail avec l'objectif de produire des traductions de haute qualité. En reconnaissant la signification historique de cette approche, il est possible de l'adapter à la société contemporaine. Nous croyons que cette approche peut amener une contribution constructive à la traductologie.
\end{abstract}

\begin{abstract}
Within the German Democratic Republic (GDR) during the period of the Cold War, a new approach was created to the processes involved in literary translation, in fact the whole publishing industry was reorganised. Recognising translation as a social practice, the GDR consciously established conditions which encompassed the whole working environment with the aim of producing high quality translations. By recognising the historical significance of this approach, it may be abstracted and adapted to contemporary society. In so doing, it is believed that it can be developed into a constructive addition to the field of Translation Studies today.
\end{abstract}

\section{MOTS-CLÉS/KEYWORDS}

professionalism, status, visibility, teamwork, quality

In contemporary society with the globalizing of economies, organisations increasingly have to balance the constraints of limited time, cost-effectiveness and quality to fulfil the needs of the client. In order for translation organisations to meet these constraints, they will be required to improve their working practices. This means that translation can no longer rely on the efforts of individual translators working by themselves. Translation Studies has to widen its scope to include the entire social environment surrounding the translation process. This article argues that the historical significance of translation as practised in the former German Democratic Republic (GDR) should not be overlooked as providing an important contribution to the field of Translation Studies. It is believed that the East German approach can be usefully developed to attain the goal of high quality translations in our contemporary society. Undeniably, the socialist experiment in the GDR did not prove to be a viable system and, with the decline of the economy, increasing discontent of the population led to the collapse of the regime in 1989. However, despite the pressures of working under a totalitarian system, much was achieved in the East German publishing scene. This 
article looks specifically at the narrower context of translation and the country's revolutionary approach to translation.

This article briefly provides some background information about East German cultural politics and, subsequently, describes the ideas of the socialist translation approach. Further, the socialist reality of translation will be described. However, reference is only made to literary translators which does not mean that technical and scientific translators are deemed of less importance. Yet, it is believed that societies tend to act more favourably towards the latter ones (with respect to a more secure economic position) and, thus, this article would like to stress the uniqueness of the East German approach by giving an insight into how this society treated literary translators and their translations. The findings are based on the study of the East German censorship files, the files of the East German Writers' Association and on interviews that have been made with ex-GDR translators and people from the field of publishing.

\section{East German Cultural Politics}

After the Second World War, the GDR - like the other Eastern Bloc states - regarded itself as a country which had just overcome the historical epoch of capitalism and was on the path to communism. Therefore it was imperative for East Germany to introduce appropriate measures to pave the way forward and avoid backsliding into capitalism. This in turn meant a complete restructuring of the social order. The ultimate aim was to create the "new socialist being" which, it was felt, could only be achieved by building and maintaining a true socialist environment. To this end, laws, regulations and other mechanisms of re-education were installed, with cultural politics being one of them. On 16 March 1950, a decree was passed whose main concern was the development of a progressive, democratic culture of the East German people.

In general, literature was assigned a powerful role in educating the population, in raising socialist consciousness and eliminating the remains of capitalist thinking. According to Alex Wedding, a widely published East German author, "Literature has revolutionary powers, each experience of art shapes the personality" (1967: 10, my translation). Certainly, books were regarded as being not only for pleasure and enjoyment, they had to steer the reader toward an ideologically desired behaviour and way of thinking. According to the official view, literature had to be partial, i.e., it had to represent socialist objectives and promote social progress. The main cultural concept was that of Socialist Realism, which meant that books had to show the new reality of a socialist world, the new political, economic and cultural conditions and the leading role of the working class; they had to create an image of people who were actively shaping their environment instead of believing that fate could change their world.

However, the "new socialist being" had also, by definition, to be an "all-round educated personality" - according to the motto, only "the reading worker is a knowing worker" (DR1/1827, my translation). It was viewed as the task of the whole society to develop a socialist culture which enabled the entire populace to participate in a highrate cultural life-style (Glücksmann 1962: 12). Hence, overall emphasis was placed on high quality books. From the early days, in the course of building an East German 
national literature, the aim was to incorporate works from the world's cultural heritage. This meant that foreign, i.e., translated literature, was viewed as an essential and enduring part of literary policy which integrated translation firmly into the literary and publishing scene. As a corollary, foreign books had to show the same high standards and had to obey to the same ideological principles as indigenous literature.

\section{Rejecting the Old Approach and Looking to the USSR}

Given that translation was recognised as a significant part of the national literature, the value and role of the socialist translator and translation were already debated in the early 1950s. The translator W. Baum, in a letter to the Berliner Zeitung from 1 February 1951, expressed the urgency attributed to that matter.

"[...] It is now time to introduce to the broadest strata of our work force the eminent literature from the USSR, from the states with a people's democracy and from all progressive authors in the entire world; [therefore] a totally new value must be attached to the issues of translation, totally different from its handling so far. The translator must no longer be viewed as the handyman for the author or publisher, but must be regarded as an artist or an expert in their own right" (VS neu 257, my translation).

Various documents in the archives reveal that, as early as 1952, in the period of socialist construction, as declared officially, the state of translation was widely expounded and analysed and serious concern about the state of affairs was expressed. In a letter to the Central Committee on 20 June 1952, Kurt Hager (member of the Party's Central Committee, member of the Politburo between 1958 and 1989, and a translator himself), described the status quo and made suggestions for a way forward for the translation profession (DR1/1886). The files DR1/1575 and DR1/1886 may serve as an example where the following criteria are listed as improvements required urgently:

- $\quad$ there were not enough translators available (with respect to either language and translation areas)

- the translators failed to be sufficiently qualified; they were not found to measure up to their work professionally, ideologically and linguistically

- universities were not called in for translator training

- there was no concept in existence to train and qualify future translator generations

- many translations were found to have been performed carelessly, frequently the language of the German translation caused difficulties for the readers and, as a result, dissemination of foreign texts was hindered

- the remuneration of translators had not been brought up to required standard and varied from publisher to publisher

- $\quad$ as to book reviews, translated books were not taken into account sufficiently, which led to a lack of important suggestions suitable to further improve the translatorial work

- translators were left to their own resources; they worked on their own, isolated without any advice or instruction by more experienced translators

- generally, translators were not aware of their responsibility and of the importance of their work

- the status of the translatorial work was too low and was in no relation to the translators' achievements

- translators were at the mercy of the publishers and their arbitrary policies 
- co-operation between editors and translators was lacking

- editors overlooked the fact that shortcomings of a translation had to be discussed with the translator

- the whole situation related to translation appeared unmethodical and the allocation of commissions seemed random

In order to remedy these inadequacies, three steps were taken. First, suggestions of any kind for improvement were invited; secondly, plans for instituting a central authority concerned with co-ordinating and guiding the translation process were made; and thirdly, a close look was taken across the border to East Germany's role model, the Soviet Union, with the desire of borrowing from the Soviet approach. It was hoped that a Marxist-Leninist translation theory could be developed and that the translation process could be reformulated in alignment with the total socialisation of the country. All of this resulted in several notions finding entry into the official discourse, many of them borrowed from Soviet concepts. Since the USSR consisted of a large number of nation-states, translation was required between texts from all these individual states, particularly between the national languages and Russian, and between non-Soviet languages and the Soviet languages. Hence, the GDR found itself in the fortunate position of being able to draw on this vast experience and to model itself on the USSR. Following the example of the USSR, it was argued at an East German translators' conference in 1954, that translation was part of literature. "Translation is not a technique or method, it is not a trade or a part of philology, but a means of literary creation. Therefore, translation is part of literature. Translation is part of a nation's literature, which is evidenced by the fact that it contributes something to the literature of the particular nation into which the book is translated. Thus, when translating books for the GDR market, nothing is added to the French or Italian literatures but purely to the East German one" (DV neu 332, my translation).

According to the Soviet model, the translation process should be redefined as the totality of all stages from the preparation of the source text to the publication of the book. The new factor here was the rejection of the isolated and individual aspect of translation and instead the collective element was to be embraced. For this collectivism the term "functional translation" was coined (again drawing on a Soviet concept) which was not intended to diminish the translator as the central figure, but rather to liberate the translator from odd, time-consuming tasks. The principal goal was high quality literature to which everything was subjected and which made necessary the co-operation of all the people involved in a project, primarily the translator and the editor.

Ideally, the translator should be what the Soviets called a "responsible translator." This meant that s/he was highly qualified regarding: the ideological content, knowledge of the history, culture and everyday life of the source country, style and linguistics and an understanding of the topic. S/he was responsible in all aspects for the translation and could also be trusted to do his/her own editing. A less qualified translator was defined to be still lacking either in language or in some ideological aspect; as a corollary, his/her work required additional effort in the form of corrections by the editor. As a result, it was maintained that the fees paid by the publishers should reflect the degree of the translator's expertise and the quality of the translation delivered (DV neu 332). 
The end product was the so-called "realistic translation," a translation from a source text in which the translator had spotted the new and the positive and had transferred it correctly, i.e., with respect to a socialist reality. Particularly during the early period of the GDR, it was believed that translation was to be partial and that the translator was to be a propagandist - similar to the socialist author. It was maintained that every translator in every country had to make decisions which did not depend only on his/her personality, nationality or experience but also on his/her ideological attitude and position in the class system. Consequently, it was proposed that, translators in a socialist country were required to be familiar with politics, cultural politics and social developments in their country and, as socialists, to be capable of assessing their country and its citizens correctly in their respective historical situation. Therefore, it was not considered sufficient for translators only to have knowledge about the country of the source text and to master a foreign language and mother tongue. They were also required, like the authors, to be knowledgeable about societal evolution and to be in touch with the leading influences in the state, so that their translations were moulded in a way that "workers and farmers could relate to" (SV neu 785, my translation). Translators were to regard their work not so much as a source of income but rather as a source of education of the population. The translators were required to "take on an active, positive approach to socialism and to be conscious of the responsibility they had to their readers," which meant, according to Werner Creutziger" "having an active relationship towards the text which, in turn, justified smaller corrections in mediocre books" (SV neu 777). Overall, it was acknowledged that - contrary to the technical translators - style and form played as important a role as the content of the book. Because of this, it was stated that it was impossible to define translation norms, because it depended on every individual case as to which translation solution was chosen (SV neu 789). Similarly, Lieselotte Remané, East German translator, argued for different approaches according to quality and importance of a particular book. Apart from a thorough training, Remané wanted to see experience, talent and conscientiousness as prime characteristics for the literary translator (SV neu 777).

Commonalities between translators and authors were highlighted. Both were regarded as creators of literary texts, both were accountable for every word, sentence or an entire book, both were responsible for the readers' comprehension of the text. Furthermore, like the author, the translator knew about the subject, the topic and the language of the book and was able to judge whether it suited his/her work style. The difference between translator and author was, as East Germans saw it, that the translator was both inferior and superior to the author. On the one hand, translators were to serve the source text and were to subordinate themselves to the authors. On the other hand, translators were required to cope with books of many different kinds and be competent in many styles. Moreover, they had to delve into the depth of the foreign culture (i.e., thinking as the foreign author) and then to transpose this to the German culture (i.e., acting as the German author), which made them superior to the author.

In the course of time, however, it turned out that a Marxist-Leninist translation theory was not realised. Occasionally, articles were published describing a particular translation problem or generalising experiences which had been made while working 
on one or many books, but the discourse there resembled rather the nature of a discussion group and did not attempt to form part of a communist theory. It has also to be said that the earlier directive by the state to translate in a partial way was too insubstantial and lacked precise definition and instruction. Therefore nobody had an idea of how to put this directive into practice, which led, in the end, to a tendency amongst translators to neglect this approach and "perform their work as normal" (Creutziger 1998: 31, my translation).

Despite the failure of a Marxist-Leninist translation theory, two key concepts had been formulated and transposed into real measures of improvement. The first was the notion that the translator was to be seen as being as valuable as the author. The second was the concept of collectiveness in the translation process. Whereas the first one made possible the membership of the literary translators within the powerful Writers' Association, the second facilitated good and fruitful co-operation between editors and translators, the loss of which all translators who have been interviewed are mourning to this day.

\section{The Socialist Reality of Translation}

\section{Central Control - Decentralised Work}

After 1952, a number of steps were taken to reorganise and improve the translation industry. It was clear from the beginning that the main principle in this re-organisation had to be "central control - decentralised work" (DR1/1886, my translation). Thus, one of the prime objectives was to set up a central institution dealing only with matters of translation. The overall goal was to enhance the quality of translations and to improve the status of translators.

As a first step, the foreign department within the Ministry of Culture installed, within its purview, a new authority, the Zentralstelle für wissenschaftliche Literatur (Central Authority for Scientific Literature), invested with the task to keep records of all prospective/planned and completed translations, technical as well as literary translations. Every institution in East Germany (publishers, translating agencies, businesses, academic institutions), concerned with translation, was required to register their projects with this authority and, after completion, to submit a copy. Also, every institution was to enquire if their planned translation had been done already, before embarking on a project, and if so, to make use of the existing version. This should avoid double translation and, subsequently, reduce unnecessary expenses for material and work force (DR1/1896). This point of rationalising was clearly formulated in the decree about registration of translations from 24 June 1954:

"The translation business is one of the most essential means to acquire foreign technical literature in order to attain the highest level in science and engineering [...] It advances our scientific and cultural progress and is of prime importance to our industry. Therefore, translation reduces expenditure and serves to rationalise the entire economy; equally, however, translation itself is to be performed and included into our planned economy as economically and rationally as possible. From this it follows that, in order to best fulfil [society's] needs, translations must be systematically controlled and subsequently be made available to the widest possible audience." (DR1/1886, my translation) 


\section{Professional Organisation}

With respect to the literary translators, the necessity of a professional organisation was recognised. The conclusion was reached that they be integrated into the Writers' Association, with the assent of the foreign office to co-operate and support the Association in all possible respects (DR1/1908). What gave rise to this move was firstly the notion that the translators should be classified as the creators of a work and therefore were classified as recreating authors (which made them fit into an organisation set up for authors); secondly that literary translators, as freelancers and unlike the technical translators, who all were employed by big translation agencies, were not represented by the Union but that they too needed a supportive body behind them. Hence, on 10 April 1953, the first meeting of the newly founded Übersetzersektion took place (VS neu 257; DR1/1908; DR1/1886). Within the Association, the translators held the same position as the authors; the same rights were granted and the same facilities were open to them. As to recreational facilities for instance, there were two work and holiday homes provided, which translators were able to use free of charge or at minimal expense. One of them was set aside for only authors, translators and their families (Arbeits- und Erholungsheim Friedrich Wolf, not far from Potsdam), the other one, a castle, had been made available to all citizens working in culture and arts from 1979 (Otto-Grotewohl-Haus in Berlin-Pankow) (personal interview with translator Ingeborg Kolinko; Walther 1999: 52; DV neu 79). Having the backing of the powerful organisation of the Writers' Association meant strong intellectual support, meant having an official representative body, meant having a platform for lectures and discussions on particular translation issues and meant the possibility of fully sponsored courses and conferences in the Eastern Bloc. Creutziger notes that "the Writers' Association generously supported the professional work of the translators and that there was never any begging or haggling for project finance" (1998: 28,30, my translation). In-service training and vocational training courses were offered, both on language issues and other topics related to translation and the world of publishing. On a regional level, talks and debates took place even more frequently and in Berlin a monthly Jour Fixe was organised which attracted plenty of participants, many of whom were nontranslators (Creutziger 1998: 33). The journal Neue Deutsche Literatur, published by the Writers' Association provided a further forum for special subject articles; and on a regular basis competitions were held and prizes awarded by the Übersetzersektion. Over the 40 years of the existence of the GDR, translators experienced progressively more improvements to their financial position and to their professional status. After having put in place a basic set of fundamental conditions in the 1950s, the Übersetzersektion underwent a re-structuring on 15 December 1967 (SV neu 785). Its new name Übersetzer-Aktiv (work team of translators) reflected that, from now on, the approach regarding translation matters was going to be even more active, committed and vigorous.

In order to be accepted into the Writers' Association, potential members had to meet certain criteria. As an organisation linked to the Unity Party, the Association manifested its closeness to Marxist-Leninist ideology in its statutes which future members had to acknowledge. The socialist maxims as stated in the statutes were:

“The East German Writers' Association recognises the leading role of the working classes and their Party in cultural and literary matters. The members of the Association 
view Socialist Realism, which is founded in Marxist-Leninist ideology, as their methodology with which to interpret and artistically reflect reality correctly. They stand firm against all theories of ideological co-existence and against penetration of literary spheres through bourgeois notions. They work actively in creating a socialist society. Their art is directed at shaping the thoughts and actions of socialist people. In so doing, they participate in the all-round construction of socialism in the German Democratic Republic and do justice to their responsibility and their patriotic duties toward the whole German people, whose future constitutes itself in the first German workers' and farmers' nation of peace. They [i.e., the members] are familiar with all humanist literary developments, past and present. They feel united with all authors in Germany and in the entire world whose oeuvre serves peace, social progress and liberation of all people exploited and suppressed" (SV neu 609, my translation).

On a professional level, "the translators, adapters and editors had to prove they had been continuously working on translation projects and that their work stood out on a high cultural level" (SV neu 553, my translation). On their application, translators were required to submit proof of the standard of their work, i.e., books they had translated, with at least one book from world literature, or with 3 to 4 other books (DV neu 60).

\section{Economic Status}

The GDR believed that only translators relieved from the usual daily worries and struggles were in a position to deliver good quality work. Therefore, a large number of measures were taken to liberate translators from many of the stresses which one finds normally connected with being a freelancer. Socially, a precautionary net was woven with a number of benefits. Benefits such as social security meant that translators could afford to fall ill without worrying about loss of income; in later years they were even granted the same position as East German workers, entitling them to additional benefits such as maternity pay, child care payments, sick pay for single mothers to be able to nurse a child and a small retirement pension (Glücksmann 1975: 278-286). All-day pre-school and school was free to their children - a further relief, financially and logistically.

Based on the progressive approach toward a new relationship between publisher and creator of a book (i.e., author and/or translator), it was evident that both parties jointly work together in constructing a socialist society. Thus, it was regarded as being in their common interest to create and disseminate socially important literature. Nonetheless, it had been noticed that the majority of publishers were still caught in the bourgeois, capitalist practices of cheating creators out of their rights (Glücksmann 1962: 18). Therefore, a nationwide copyright law was installed (1956) to protect authors and translators and their rights to their work.

The most powerful and ultimate benefit however was introduced as early as 31 May 1955 (Glücksmann 1962: 19; SV alt 1118) in the form of the Normalverlagsvertrag (standard contract for literary translators). Four years before, in 1951, W. Baum reported on endeavours within the Writers' Association to prepare a draft contract and to submit it to the East German ministries and the Publishers' Association in the near future. This draft was to fulfil all requirements with respect to improvement of the quality of translations and to the economic security of the translators (VS neu 257). This standard contract was achieved through co-operation between 
the Writers' Association, the Ministry of Culture, the Association of booksellers (Börsenverein der Deutschen Buchhändler, Leipzig) and the Union, and secured the translators a fair basic payment. It was a model contract which was binding to every publisher and translator entering into a business agreement. A basic fee was arranged for every page of the manuscript. A third of this fee was payable to the translator on conclusion of the contract agreement, another third on submission of the manuscript and the last third on the publisher's acceptance of the manuscript. This meant that the translator was paid a major part of his/her fee before even beginning the actual work on the translation. This basic fee was determined by two elements, firstly according to the difficulty of the source text language and, secondly, the quality of the translation, i.e., did the translator need much support from the publisher or was the manuscript ready for setting? (a concept which was rooted in the Soviet model as described earlier). A further incentive in the contract was a clause stipulating profitsharing for reprints to be paid to the translator which was effective for copies up to a print volume of 30,000 (as print runs used to be unusually high in East Germany, this clause was of great value to the translator). If a book or text was sold to another publisher, the translator received royalties from the profits of the rights to the book. Another paragraph of the contract deals with the free copies of the book which were presented to the translator (these were 10 for the first print run, and 5 for every following edition). Should the translator wish to buy additional copies for personal use, the publisher was obliged to supply the translator with them at a reduced price. Also as early as 1955, the publisher was required to cite the translator's full name on the title page. It should be noted that not only the translators' rights but also their duties were recorded in the contract. The translators were required to discuss all comments and corrections made by the editor and accept well-founded corrections and improvements; they also had to exercise the final editing of their translation and to proofread the galleys. As soon as the translation was submitted, all rights to it passed on to the publisher.

Once established, this standard contract underwent amendments and enhancements approximately once every decade. Similarly, the translator's financial and social position was improved step by step throughout the existence of the GDR.

\section{Training}

In 1952, the decision was taken to systematically train literary translators (DR1/1886) or, as was expressed at the first meeting of the Übersetzersektion in 1953, "to develop and train translators in such a way that publishing houses can rely on them" (VS neu 257, my translation). To this end, the foreign office obtained information from the publishers about their previously and presently employed translators. Questions were asked regarding nationality, ideological and professional training, employment status (freelance, full time, etc), the time at which the foreign language was mastered, membership of the Unity Party or any other association and the present commission set by the publisher, in order to organise a central register and from there steadily provide further training as deemed necessary. In the following years more and more translators and editors completed a language course at a university. Not unexpectedly, there was also a requirement to read literature representative of the foreign 
culture as well as to familiarise oneself with the contemporary political literature and the theory of Marxism-Leninism. From 1974, a further university course (i.e., Studienrichtung Sprachmittler) was established in order to give training particularly to interpreters, technical and scientific translators, some of whom later found jobs in publishing houses.

\section{Collective Spirit}

Teamwork and collaboration were a well-esteemed principle. In every industry in the whole of the GDR, so-called collectives were at work, i.e., groups working together closely on the same project and supporting each other in every respect. From early childhood, teamwork (or rather collective work) was drilled into every individual, which meant full commitment to the new social order and subordination of the interests of every individual to the interests of the collective. It cannot be denied that co-operation was vital in order to survive a lifestyle beset by obstacles and difficulties which had to be overcome and which would have hardly been feasible for an individual struggling on their own. Hence, teamwork had become second nature to the East Germans. Because of this and also drawing on the Soviet model (as mentioned before), collective work in the publishing industry was the order of the day. Editors as well as translators put their professional pride into producing high-quality work and they realised that the best results were obtained through teamwork

"As opposed to the capitalist system, where the author [and translator] is left to him/ herself during the creative process and where his/her say finishes at submission of the manuscript, in socialist countries the publisher's participation already commences with the work on the manuscript and the author's [and translator's] participation continues until the selling of the book" (Wendt 1967: 213, my translation).

It should also be mentioned that there was another reason for this co-operation both translators and editors knew that co-operation would help in sailing the murky seas of censorship and would increase the chances of a book being published.

In order to smooth the path of a translation and to provide the translator with expert advice, publishers had names of experts and evaluators readily at hand to ensure that a book and its translation was assessed favourably when submitting it to the censorship authority (for every book, assessments had to be written by at least one evaluator, which were submitted together with the publisher's commentary and application). Frequently, translators themselves were called in to act as evaluators, or they had to write glossaries, indexes or the all so important afterword ${ }^{2}$; whichever the translator produced was subsequently a matter of a collective agreement between him/her and the editor, at a further stage, then between the editor and the editorin-chief and the head of the publishing house. Publishers, too, were encouraged to co-operate with other publishers, nationally and internationally, with the aim of continual exchange of ideas about matters of translation (DR1/1234). Some general advantages of international collaboration were: exchange of experiences, exchange of publishers' topical plans, joint development of manuscripts, recommendation of books to be published, speeding up of translation processes, simplification of mutual financial settlements and savings in foreign currency spending. 


\section{Visibility of the Translator}

As has been shown, in this striving for ultimate quality and excellence, initiatives had been taken, the entire value system of the society had been turned around and new norms had been created. The GDR had taken on board the idea that the whole of society was accountable for the outcome of a translation and that the question of quality could not be left to the sole responsibility of one individual, namely the translator. In addition, what resulted from this was a remarkable rise in the status of translators within society, and with public awareness came more respect. Translation had become an issue of a whole society and was no longer a marginalized profession. All the interviewees stated that they fully supported the changes in their profession and that they were committed to their work as they regarded literature as an enrichment to society. Some contended that they felt more privileged because of the fact that translators had studied a foreign language and had a university degree whereas the general populace had not. Hence, they frequently noticed that people would look up to them admiringly.

By and large, East German translators were in a position to dedicate themselves fully to their work. Not only were they socially secure, they also were under no pressure to deliver translations to tight deadlines. There was not the competition of a market economy, and everything was centralised and had to be planned which took considerable time, often more time than originally expected. What is more, there was no competition and rivalry between the individual translators themselves, which can be attributed to the fact that most of them were content with what life offered them. Also in the GDR, as a planned society, the educational system was planned to be in alignment with the job market, which meant that the right numbers of pupils and students were trained into the right job. Open unemployment did not exist. Therefore, nobody took up translating in order to avoid being unemployed. Similarly, the 'hobby sector of bored housewives' did not exist because women, like men, had fulltime jobs. Both these facts left the industry to people interested in making a career out of translation.

All of the translators interviewed were very aware of the position they held in society. All of them felt they had been widely respected by the publishers and also by the general public for what they were doing. Translating in the GDR was not simply an isolated job behind a typewriter. Translators had plenty of opportunity to get in touch with their audience as they were sent round the country to read from their works. This is evidenced by a letter from the Writers' Association mentioning readings and talks by translators to establish direct contact with the audience. The Association states that they "have agreed with the Department of Literary Propaganda [...] that the libraries and book shops will be distributed with appropriate briefings and a list of those members of the Übersetzersektion (including address and selected details of the books translated so far) who have shown an interest in being invited to readings" (SV neu 791, my translation).

Translation was indeed a very visible process in East Germany with respect to the impact translated literature had on the market. Reading was a widely pursued spare time activity, easily understandable in a country which had little else to offer in terms of private entertainment. Moreover, the majority of East Germans did not have the financial means to travel nor the possibility to cross the Iron Curtain and explore 
western countries. For this reason, books (and especially translated books) acted as a source of information, opening a view to another fascinating world from which they were excluded. This led to a wide general awareness in the public about translation and readers knew about forthcoming publications, announced in the official advance notices by the book industry. Translated books, particularly from western authors, were awaited eagerly and, once in the shops, sold out within the hour.

This extraordinary position of translators is summed up in a quote by Creutziger: "many translators had thought their position satisfactory. They were very aware of the position of their colleagues in West Germany and if they had lived in the west themselves, they would certainly not have chosen to be a translator" (1998: 14, my translation).

\section{Conclusion}

From research into the history of literary translation in the GDR, it has been shown that the sociological approach to the translation process appears to have provided an environment favourable to the production of translations of a higher standard, i.e., increased training, expert reviewing and consultancy, quality controls, etc. It is striking that such an effective approach was developed 50 years ago and was operating behind the Iron Curtain with little benefit to the rest of the world. It would be unfortunate if the lessons learned by the GDR could not be brought forward to benefit the translators of today. Admittedly, there may be problems with the political and ideological stance in the GDR, however, as has been shown, valuable insights can be gained from the East German approach which may be applicable in contemporary societies.

\section{NOTES}

1. Werner Creutziger is a translator himself and, for three years, was head of the Übersetzersektion (department for literary translators) within the Writers' Association.

2. Such an afterword served as a justification for the selection of the book and how it would benefit the reader. The formulation of this afterword and the explanation of certain concepts in the light of a socialist ideology determined how easily the book would pass the censors; particularly in the case of a controversial book, the afterword could determine the book's fate within the censorship authority.

\section{REFERENCES}

Creutziger, W. (1998): "Die Zukunft und der Staat. Literaturübersetzer in der DDR" in W. Lenschen, (1998 ed.) Literatur übersetzen in der DDR, Bern, Peter Lang.

Glücksmann, A. (1962): Theorie und Praxis der Pressearbeit. Das Urheber-, Verlags- und Presserecht der Deutschen Demokratischen Republik, Leipzig, Karl-Marx-Universität.

Glücksmann, A. (1975): Gesetze. Verordnungen, Abkommen und sonstige Dokumente zum Urheber-, Verlags - und Presserecht der Deutschen Demokratischen Republik, Leipzig, Karl-MarxUniversität.

Ministerrat der Deutschen Demokratischen Republik, Ministerium für Hoch- und Fachschulwesen (1974) Studienplan für die Grundstudienrichtung Sprachmittler; Nomenklatur-Nr. 73701 76701, Berlin.

WALther, J. (1999): Sicherungsbereich Literatur, Berlin, Ullstein.

Wedding, A. (1967): “Unsere Verantwortung" in Beiträge zur Kinder- und Jugendliteratur 9.

Wendt, D. (1967): Die Beendigung des Verlagsvertrages im neuen Urheberrecht der Deutschen Demokratischen Republik (Ursachen, Voraussetzungen, rechtliche Regelung und Rechtswirkungen dargestellt am Beispiel des Buchverlagsvertrages) Ph.D. Thesis at Humboldt University, Berlin. 
510 Meta, XLIX, 3, 2004

Censorship Files:

DR1/1234

DR1/1575

DR1/1827

DR1/1886

DR1/1896

DR1/1908
Files of the Writers' Association:

DV neu 60

DV neu 70

DV neu 332

VS neu 257

SV alt 1118

SV neu 553

SV neu 609

SV neu 777

SV neu 785

SV neu 789

SV neu 791 